\title{
EFFECT OF FOREIGN COMMISSIONERS, ETHNIC COMMISSIONERS, FEMINISM COMMISSIONERS TOWARDS CSR DISCLOSURE
}

\author{
Anita Ade Rahma ${ }^{1}$ \\ Faculty of Economic \& Business \\ Universitas Putra Indonesia "YPTK" Padang \\ Anita_aderahma@upiyptk.ac.id*
}

\author{
Febri Aldi ${ }^{2}$ \\ Faculty of Economic \& Business \\ Universitas Putra Indonesia "YPTK" Padang \\ Febri_aldi@upiyptk.ac.id
}

\begin{abstract}
The study aims to test whether the foreign commissioners, ethnic commissioners, and feminism commissioners influence CSR disclosure. This study used a sample of 20 companies LQ-45 are listed on the Stock Exchange from 2015 to 2017. CSR disclosure using the GRI-G4 standard. Ethnic commissioners focused on the presence of ethnic Chinese. The results of this study prove that the foreign commissioners' variables did not affect CSR disclosure. While on the contrary, ethnic commissioners and feminism commissioners gave a positive effect on CSR disclosure. The existence of ethnic Chinese in the board profitable companies to improve disclosure of CSR index. Likewise, the role of women is needed for the breadth of CSR disclosure.
\end{abstract}

Keywords:

CSR disclosure; foreign commissioners; ethnic commissioners; feminism commissioners; corporate governance

\begin{abstract}
ABSTRAK
Penelitian bertujuan untuk menguji apakah dewan komisaris asing, etnis dewan komisaris, dan feminism dewan komisaris mempengaruhi CSR dislosure. Penelitian ini menggunakan sampel 20 perusahaan LQ-45 yang terdaftar di BEI dari 2015-2017. CSR disclosure menggunakan GRI-G4 standard. Etnis dewan komisaris terfokus pada keberadaan etnis Cina. Adapun Hasil penelitian ini membuktikan bahwa variabel dewan komisaris asing tidak berpengaruh terhadap CSR disclosure. Sedangkan sebaliknya, etnis dewan komisaris dan feminism dewan komisaris memberikan pengaruh yang positif terhadap CSR disclosure. Keberadaan etnis Cina dalam dewan menguntungkan perusahaan untuk meningkatkan index CSR disclosure. Begitu juga peran wanita sangat dibutuhkan demi luasnya CSR disclosure.
\end{abstract}

Kata Kunci: $\quad$ CSR disclosure; dewan komisaris asing; etnis dewan komisaris; feminism dewan komisaris; corporate governance

JEL Cassification: M410; G340

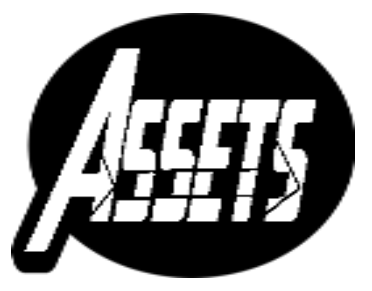

ASSETS

Jurnal Akuntansi dan Pendidikan

Vol. 9 No. 1

Hlmn. 16-29

Madiun, April 2020 p-ISSN: 2302-6251 e-ISSN: 2477-4995

Artikel masuk: 19 Desember 2019 Tanggal diterima: 20 April 2020 


\section{INTRODUCTION}

Globalization is evidence that Corporate Social Responsibility (CSR) is a crucial thing (Zaid, Wang, \& Abuhijleh, 2019). Where CSR for a corporation is an activity carried out for the sake of corporate sustainability. CSR is a company's commitment to improving public welfare through wisdom in business practices and enterprise resource contributions (Nuryaman, 2013). This is closely related to accounting science that serves as a means of expressing their social activities transparently in financial statements form. According to Lusiana \& Rahma, (2017), the company's annual report is a guideline for the investors to invest in a company. According to a survey conducted by the Global Reporting Initiatives (2008) trend CSR Reporting in the World and Indonesia, there was a significant enhancement over the companies' number that make CSR report. It is known as a sustainability report, from about 300 in 1996 to 3,100 in 2008. Previously, reporting or disclosure of CSR, which is simply a voluntary statement by the company, but now the government realizes the importance of the company's CSR reporting. This was evidenced by the already passed several laws regulating CSR disclosures made by the company. CSR disclosures made by the company not only to comply with regulations that have been enacted but also beneficial to the survival of the company or maybe called a long-term investment for the company. CSR activities that companies do show that the companies concerned in the environment and surrounding community welfare and well-being of the employees of the company. Moreover, the benefits of the operations conducted by the company not only felt or enjoyed by the company's internal parties but also the wider community. In Indonesia itself has a lot of companies undertake CSR activities and report in the annual report the company to attract investors.

CSR is also influenced by factors of good corporate governance, such as foreign commissioners, ethnic commissioners, and gender commissioners. The diversity of nationalities commissioners is wisest and intelligent to increase the score of CSR (Barka \& Dardour, 2015). According to Yunos, Ismail, \& Smith (2012), a multi-ethnic group does not inhibit the company's ability to achieve harmonization in its financial statements. Gender commissioners focused on the gender of women, where women's presence appointed to the company's board. This is based on the grounds of women can be a signal that the performance of the company is running well, not as a sign that in the future women can make something that impacts both companies (Calabrese, Costa, Ghiron, \& Menichini, 2018). Love for someone to spill their blood encouraging individuals to work seriously and very carefully. Therefore, when people who work in companies are natives then the implementation of the work will be taken very seriously, one of them in maintaining the environmental sustainability of biological resources and non-biological. According to Oxelheim \& Randøy (2003), foreigners' presence on the commissioners' board has triggered information disclosure that is expected to enhance the company's credibility. That is an effort to increase CSR disclosure.

Under Majeed, Aziz, \& Saleem (2015) and Rahindayati, Ramantha, \& Rasmini (2015), Nationality had a positive and significant impact on CSR disclosure. The existence of a foreign board can be seen from the presence of foreign citizens in commissioners' board composition. According to Ayuso \& Argandoña (2007); Khan, Khan, \& Saeed (2019), foreign's board presence has a significant role in supporting CSR reporting. According to Branco \& Rodrigues (2008), a foreign board can raise the issue of causality CSR disclosure. Foreign nationals, in general, have a high awareness (Dewi \& Monalisa, 2016) and concern about the condition of a clean environment, education, 
health, and so on (Erhardt, Werbel, \& Shrader, 2003). Attitudes and habits that will then be taken also when he worked in other countries. In the end, habits, and attitudes that will influence management decisions in implementing CSR activities.

Indonesia is a country with many races and one that had a big contribution to the business world in Indonesia are ethnic Chinese (Nussy, 2013). Indonesia has a diverse ethnic, one of them is ethnic Chinese who have a big role in the Indonesian economy. Many companies where it is among the commissioners of ethnic Chinese. Ethnic Chinese are considered to have a high level of discipline that makes the indigenous ethnic formerly lost from ethnic minorities.

Ethnic Chinese are even able to beat the position of indigenous ethnic today. According to Yunos et al. (2012), the Chinese people are believed to have the power of persuasion and strong confidence in leading the company. Erhardt et al. (2003) argue about ethnic representation in directors' board could upgrade business financial performance. Tan (2005) found that ethnic Chinese were more individualistic than wither. Chinese people like delegating leadership style, a greater authority, and more open decision-making. This is in line with Suhardjanto \& Permatasari (2010) finding that the Chinese are task-oriented with any type of work to be successful. Personal characteristics affect major commissioner disclosure practices (Bustami, Nasruddin, Sen, \& Ng, 2011; Mullins \& Soetanto, 2013). According to research conducted by Osemeke \& Osemeke (2017), the main idea of a commissioner is influenced by ethnic background.

Lückerath-Rovers (2013) revealed that the women's presence on the company board was divided into two perspectives of explanation. The two perspectives were business and moral. Both of them are divided into two arguments for equality or equality of opportunity and arguments are similar to or equal representation. The business perspective argument focused on the fact that women's presence on the company boards is sub-optimal for the company. Bear, Rahman, \& Post (2010) reveals that women have an attitude of prudence is soaring, tend to evade the risk, and are more conscientious than men. The side is what makes women do not rush into making a decision so that the presence of women on the board of the company is said to help decide which is more precise and less risk. Galbreath (2018) states that women think and act in more detail in decision-making. They tend to analyze problems from beginning to end before decision-making. Decision-making results in a closer resolution of the problem and alternatives.

Empirical research also has many concluded that the presence of the woman can contribute significantly to the performance of the company. Women board members said to be more participatory, more organized, more determined, more critical, and can further create a better working atmosphere (Calabrese et al., 2018; DEZSŐ \& ROSS, 2012; McDonald, Keeves, \& Westphal, 2018). Women's presence in board structure indicates a further increase in the diverse perspective board members that will affect corporate decisions (Glass, Cook, \& Ingersoll, 2016; Odriozola \& Baraibar-Diez, 2018; Williams, 2003). However, some studies reveal that women's presence will undermine the company's performance due to lack of experience, role emotional than rational domination, culture, and the slow pace of decision-making (Abdul, Marzuki, Jaafar, \& Masron, 2018; Cook \& Glass, 2018; Galbreath, 2018; Giannarakis, 2014; Ibrahim \& Hanefah, 2016; Kamangari \& Gerayli, 2017; Sudana \& Arlindania, 2011).

\section{METHOD}

By the research objectives and problems studied and formulated, the research that the author can be classified in quantitative research. Here are described and given 
an overview of the Influence of Gender BOC, the BOC and Ethnic Nationality BOC Against CSR disclosure in LQ45 company listed in the Indonesia Stock Exchange (IDX).

This variable has a free variable that Gender BOC (X1), Nationality BOC (X2), and Ethnic BOC (X3) and the control variables namely profitability, leverage and size company. While the dependent variable is the CSR disclosure (Y).

Table 1. Variables and Operational Definition of Variables

\begin{tabular}{|c|c|c|c|}
\hline Variables & Definitions & Measurement & Source \\
\hline $\begin{array}{l}\text { Foreign BOC } \\
(\mathrm{X} 1)\end{array}$ & $\begin{array}{l}\text { Presence of foreign } \\
\text { nationality on board }\end{array}$ & $\mathrm{DKA}=\frac{\mathrm{A} \_\mathrm{KOM}_{\mathrm{K}}}{\mathrm{SUM} \mathrm{KOM}_{\text {...(1) }}}$ & $\begin{array}{lr}\text { Abad, } & \text { Lucas- } \\
\text { Pérez, Minguez- } \\
\text { Vera, \& Yagüe } \\
(2017)\end{array}$ \\
\hline $\begin{array}{l}\text { Ethnic BOC } \\
(\mathrm{X} 2)\end{array}$ & $\begin{array}{l}\text { Ethnic background is the } \\
\text { origin of a person with } \\
\text { characteristics and } \\
\text { different behavior patterns }\end{array}$ & $\mathrm{EDK}=\frac{\mathrm{C} \_\mathrm{KOM}_{-}}{\text {SUM_KOM }_{\text {... }}(2)}$ & $\begin{array}{l}\text { Harjoto, } \\
\text { Laksmana, } \\
\text { Yang (2019) }\end{array}$ \\
\hline
\end{tabular}

Feminism

$\mathrm{BOC}(\mathrm{X} 3)$

Contribution of women to the performance of the company

Company's ability to

Profitability generate capital gains by

(C1) all who work in it.

The ratio that describes the

Leverage relationship between the

company's debt to equity a value of 1 if there are women on the BOC, a value of 0 if there are no women on BOC

Antoro \& Hermuningsih (2017)

$$
\mathrm{ROE}=\frac{\mathrm{EAT}}{\text { total capital }}
$$

Rahma, Mary, \& Gozali (2019)

$\mathrm{DER}=\frac{\text { total debt }}{\text { total capital }}$

Rahma, Lusiana, \& Indriani (2019)

Conveying process on social and environmental CSR impacts of the company's disclosure activities towards its CSRDit $=\frac{\text { QCSRDi }}{\text { SQMAX }} \ldots(5)$

Alazzani, WanHussin, \& Jones (2019) shareholders, creditor, employees and the community as a whole.

\section{Notes :}

DKA : Diversification of citizenship on the structure of the company's board of commissioners

A_KOM : Number of foreign citizenship in the company commissioner structure

SUM_KOM : Number of company commissioners

EDK : Ethnicity commissioners board

C_KOM : Number of Chinese Ethnic in the company's board of commissioners structure

ROE : Return on Equity

EAT : Earning After Tax

DER : Debt Equity Ratio

CSRDit : CSR disclosure of company i

QCSRDi : Number of items disclosed i

SQMAX : The maximum item CSR disclosure 
The population is the whole of the object of research consisting of certain subjects that meet the required research characteristics. The population used in this study as many as 45 companies LQ45 listed in IDX that publish and publicize the annual financial statements and Sustainability Report period 2015-2017. LQ45 is a company with the best reports and highlighted shares.

The sample is part of the population that has fulfilled all the requirements needed in research. Sample research was done by purposive sampling method. It means that the population and in accordance with the desired research sample. The sample used in this study had to meet the criteria for purposive sampling is desired by the researchers is the number of samples is 20 companies listed on IDX with a total of 60 observations annual data company. Some of the criteria used to take the sample in this study are in Table 2 as follows.

Table 2. Sampling Procedures

\begin{tabular}{lc}
\hline Information & Amount \\
\hline LQ45 companies listed on IDX 2015-2017 & 45 \\
Companies incomplete publish Sustainability Report in 2015-2017 & $(8)$ \\
Companies that do not use the standard GRI-G4 & $(17)$ \\
\hline The number of companies that qualify & $\mathbf{2 0}$ \\
\hline
\end{tabular}

Statistical models used in the regression test in this research is

CSRDit $=\beta 0+\beta 1 D K A i t+\beta 2 E D K i t+\beta 3 F$ Kit $+\beta 4$ ROEit $+\beta 5$ DERit $+e$.

Notes:

CSRD $=$ CSR disclosure

DKA $=$ Foreign commissioners

EDK = Ethnic commissioners

FDK $=$ Feminism commissioners

ROE = Return on Equity

DER = Debt Equity Ratio

it $\quad=$ firm $\mathrm{i}$ in year $\mathrm{t}$

\section{RESULT AND DISCUSSION}

This research uses the LQ-45 company sector listed on the Indonesia Stock Exchange as a research sample. Based on criteria Samples and sample procedures have been done, obtained 20 companies as a research sample by the amount of 60 observations. Data used in this research was taken from the annual report and company sustainability reports. The test results of CSR disclosure variables descriptive statistics, foreign commissioners board, ethnic commissioners board, feminism commissioners board, profitability and leverage in the LQ-45 company listed on IDX 2015-2017 shown in table 3.

Table 3. Descriptive Statistics

\begin{tabular}{llrrrr}
\hline Variables & N & Minimum & \multicolumn{1}{c}{ Maximum } & \multicolumn{1}{c}{ Mean } & Standard Deviation \\
\hline CSRD & 60 & 0.077 & 0.989 & 0.324 & 0.182 \\
DKA & 60 & 0.000 & 100.000 & 19.309 & 29.164 \\
EDK & 60 & 0.000 & 0.830 & 0.146 & 0.212 \\
FDK & 60 & 0.000 & 1.000 & 0.350 & 0.481 \\
ROE & 60 & -27.630 & 119.680 & 13.426 & 22.877 \\
DER & 60 & -3.330 & 3.640 & 0.963 & 1.129 \\
\hline
\end{tabular}


Notes: CSRD (CSR disclosure), DKA (foreign BOC), EDK (Ethnic BOC), FDK (Feminism BOC), ROE (Return on equity), DER (Debt equity ratio).

Table 3 shows that the total observation data obtained in this study were 60 years of observation by observational studies from 2015 until 2017. Variable Disclosure of CSR is the company disclosed the lowest 0.077. Disclosure of CSR, while the highest reaches 0.989 . The overall CSR Disclosure average owned the whole company a high profile in the Indonesia Stock Exchange reached 0.324 with a standard deviation of data for 0.182. The lowest CSR Disclosure was disclosed by INCO companies in 2016, from the available data it appears that this disclosure decreased very dramatically from the previous year. This was influenced by the declining financial performance that year so that CSR was minimally implemented while the highest CSR Disclosure was achieved by AKRA in 2015. Most samples do CSR disclosures in categories environment. This is because more sample companies use natural resources and surrounding environment. So that CSR is more a lot is done through recovery environment

Variable foreign BOC (DKA) can be drawn that the lowest level of foreign commissioners who owned one of the LQ-45 in the Stock Exchange 0.00\%, while the highest value of commissioners who owned one of the LQ- 45 in the BEI is $100 \%$. The overall value of the average foreign commissioners of the company LQ-45 in the BEI is 19.309 with a deviation standard of 29.164. The average value obtained from this study proves that the presence of foreign commissioners is still fairly minimal. This is due to the regulations owned by several companies that are sampled in this study, namely the structure of the board may only be filled by Indonesian citizens and also other companies have a minimum limit of national diversity in commissioners' board structure. This of course also greatly influences the control of the company and the power of the Indonesian board of commissioners.

Ethnic BOC can be drawn that the lowest value of ethnic commissioners who owned one of the LQ-45 in the Stock Exchange amounted to 0,00\%, while the highest value of ethnic commissioners who owned one of the LQ- 45 on the Stock Exchange was $83.00 \%$. Overall the average value of ethnically owned companies LQ-45 in the BEI is 0.146 with a standard deviation of 0.212 . From these results, it can be seen that ethnic Chinese have not yet dominated the structure of the board of commissioners. Companies that are sampled in general are Javanese, Batak and others. The company that has the highest ratio is because the company is a family company, which is a member of the board hereditary from the family tree. Of the 20 companies sampled, 11 of them did not have an ethnic Chinese board of commissioners during 2015-2017.

Variable feminism BOC can be drawn that the value of Feminism commissioners the lowest owned by one of the LQ-45 in the Stock Exchange amounted to 0, while the value of Feminism commissioners supreme owned by one of the LQ-45 in the BEI is 1. The mean value of feminism commissioner shows that the sample company has female members in the ranks the board of commissioners can be categorized quite dominates and gives diversity to the board that is as much as 35\%. From these averages, it can be concluded that there are quite a lot of women on the council. Many positive things both in terms of actions, ideas, and decisions that women have for company advancement.

Women can provide their color and strength for the company. It is also evident that gender equality is fairly real in all companies. There are no more limits in leading and making decisions. 


\section{Panel Data Regression Analysis}

Based on the test results the $t$-statistic has to be obtained a summary of the results shown in Table 4 below:

Table 4. Results of Hypothesis Testing

\begin{tabular}{lcccc}
\multicolumn{1}{c}{ Variables } & Coef & Std Error & t-stat & Prob. \\
\hline DKA & -0.001 & 0.000 & -0.833 & 0.401 \\
EDK & 0.280 & 0.830 & 0.146 & $0.011^{*}$ \\
FDK & -0.095 & 1.000 & 0.350 & $0.074^{* *}$ \\
ROE & 0.000 & 119.680 & 13.426 & 0.758 \\
DER & 0.001 & 3.640 & 0.963 & 0.953 \\
C & 0.325 & 0.041 & 7.765 & 0.000 \\
\hline Note: & $*$ The significance level at 5\% respectively & & \\
& ${ }^{* *}$ The significance level at 10\% respectively & &
\end{tabular}

Based on Table 4, the results demonstrated that the foreign commissioners' coefficients valued -0.001 which means the more the level of foreign commissioners will reduce CSR disclosure. This is reinforced by the value prob. 0401>0.05 (level of significance), which means foreign commissioners did not significantly affect CSR disclosure. The results can be interpreted that the commissioners of foreign nationality no influence increased or decreased expression of CSR. Citizenship status owned by the commissioners is no guarantee of increased disclosure of CSR in any public company in Indonesia. According to Rahindayati et al. (2015), Nationality indicates where an individual comes from, or where the groundwater or place of birth of an individual. Individuals who work at companies that work at foreign companies have a level of loyalty and professionalism at work. In general, foreigners who work at foreign companies have a salary-oriented orientation, while the element of loyalty does not necessarily emerge, but migrants who work at the company where they are born will be more professional and loyal at work.

A nationality element created to love and fanatical country that became the birthplace. National values also affect the performance of an individual in the work. Nationality is one of the factors that affect an increasing number of disclosures on the company's CSR (Majeed et al., 2015). The case may be the love of the homeland encourage individuals to lead the company tried to preserve the environment, ranging from biological resources to the sources of human power, the preservation is needed to safeguard the State assets.

Commissioners board chairman coming from Indonesia or which are derived from a foreign nationality has nothing to do in the disclosure of CSR. The commissioners' board has responsibility for the work, whether its chair Indonesian nationals or foreign nationality is responsible for the disclosure of CSR. These results correspond to research by Rusmanto, Syahbandiah, \& Waworuntu (2014) found that the commissioners with the status of foreign nationals did not significantly affect the amount of disclosure of CSR in any public company in Indonesia. The results obtained imply that citizenship status held by a board manager is no guarantee of increased CSR disclosure in any public company in Indonesia.

Ethnic commissioners variable regression coefficient value which is equal to 0.280 with a value prob. 0.011> 0.05 (significance level), which means ethnic commissioners significant effect on CSR disclosure. This is concomitant with research Haniffa \& Cooke (2005) that the companies' behavior included in practices disclosure of ethnic background influenced commissioner. Ethnic Chinese were able to expand 
CSR disclosure. Although the study was not all companies are dominated by commissioners who are Chinese, but the obvious presence of ethnic Chinese on the directors' board has a higher power control in expressing CSR. This is caused by members of the Chinese characters, which in implementing their business is very professional, giving priority to progress the sustainability of the company, is not merely personal interest.

Besides, members of the Chinese uphold transparency in all activities of the company. This is done primarily for investor satisfaction and loyalty to the company. The more satisfied investors on company performance, investors are also more loyal to the company. As well as this is also a broad impact to prospective investors. These results are supported by research (Suhardjanto \& Permatasari, 2010), which states that there are differences in CSR disclosure by commissioners who have Chinese ethnic background with other ethnic groups. And in line with the study by (Louis \& Osemeke, 2017; Said, Joseph, \& Sidek, 2017). However, this is contrary to research where ethnic diversity is not able to expand CSR disclosure (A. Khan, Muttakin, \& Siddiqui, 2013; I. Khan et al., 2019; Ramasamy, Ling, \& Ting, 2007).

According to Wan Mohammad, Wasiuzzaman, \& Nik Salleh (2016), policies to improve the economic position of minority communities in pushing the government's reform measures to increase the participation of ethnic minorities in correcting economic imbalances between different ethnic communities. China is the ethnic composition of the population of Indonesia. The existence of ethnic Chinese who formerly belonging to minorities can't be underestimated. Circumstances have changed in this globalization era ethnic minorities have been developed and mastered almost all business activities in Indonesia

Based on the results of the first hypothesis testing using feminism commissioners variable values obtained prob. amounting to 0.074 . In the stage of testing is used by $10 \%$ error rate. The results obtained show that the probability of $0.074<0.10$ (significance level) so that it can be concluded that feminism commissioners significant effect on CSR disclosure. These results can be interpreted that companies that have women who are on the board of commissioners with a certain percentage in the company can perform with good CSR disclosure. Women's presence on commissioners board is related with good CSR and adhere to social norms and values. The phenomenon of gender diversity is already a common thing in Indonesia companies. Women commissioners contribute to the assessment and CSR disclosure in high profile companies in IDX.

At this time large corporate companies in Indonesia provides an equal opportunity for each individual to occupy important positions, it is evident from the women who are on directors and commissioners board. At this time the woman is considered to have equality with men. In general, modern women are very conscious of the importance of education, as a result, they can work with professionals, and managed to occupy important positions in various companies. Women also judged to have an important role to boost performance because they have a high appeal, especially for men, besides women meticulous in work despite relying more on feelings than logic.

According to Alazzani, Wan-Hussin, \& Jones (2019), describe the gender distribution of men and women who occupy positions of board members. Isa \& Muhammad (2014) said that the woman on board an effect on the disclosure of CSR in any public company in Nigeria. The analysis model shows that the women's presence 
as directors redounds significantly in improving CSR disclosure amount in company with any public company in Nigeria.

Gender variations affect the increased CSR disclosure, in the results of these studies looked either men or women who occupy the same positions as commissioners equally oriented to the development of CSR (Dani, Picolo, \& Klann, 2019). The council became the main mechanism in the implementation of corporate policies. Attributes that are inherent in the person of the council provide a vital role in the company's response to the pressures posed by external parties, such as investors, creditors, consumers, governments, community organizations, and other stakeholders (Zhang, Zhu, \& Ding, 2013). This is because they have the ability and authorization to decide, control and oversee a policy that would affect the company's results or outcomes. The presence of the concept of good governance was revealed since the case of Enron, WorldCom, and other cases are caused by poor business ethics (MacHold, Ahmed, \& Farquhar, 2008). Therefore, there was some alternative in balancing the ethics of the business, namely through the lens of feminist ethics. The feminist ethical theory emphasizes the relationship (socialist) in doing a task. The presence of women in the council will provide a better work atmosphere.

Perceptions of women in gender diversity in a company increasingly changed. This view of the woman who was supposed to work at home to be omitted, changes in this globalization era requires women to career and have an important position in a company. Cook \& Glass (2018) reveals that women have an attitude of prudence is soaring, tend to evade the risk, and more meticulous than men. The side is what makes women do not rush into making a decision, Galbreath (2018) states that think and act in more detail in decision-making. They tend to analyze problems from beginning to end before decision-making. Decision-making results in a closer resolution of the problem and alternatives.

At this time the gender is not a differentiator that affect CSR disclosure. Either male or female at this time was the same as having a strong awareness of the disclosure of CSR. The situation shows that any individual who distinguished at the same gender has had a high awareness to implement CSR disclosure in the company. The existence of women as directors contributes significantly to increasing the number of CSR in the company (Bear et al., 2010; Majeed et al., 2015; Odriozola \& Baraibar-Diez, 2018).

The control variables used in this study are profitability and leverage. Profitability and leverage do not affect CSR disclosure. The test results show that profitability has no significant effect on CSR disclosure. This means that companies with high profits are not on a regular basis will significantly reveal wider CSR. Companies that have profitability height is not necessarily more social activities because of more companies profit-oriented. Management is more interested in focusing disclosure financial information only and assumes no need to report things that can be interfered with information about the company's financial success such as CSR. Some CSR activities require funding by the company so as such profitability is used as a source of CSR funding carried out by companies. In such conditions, management seems to be utilizing the profitability of the company as a better attraction than CSR disclosure.

The results of this study are consistent with the research of Respati \& Hadiprajitno (2015) where profitability has no significant effect on CSR disclosure. The leverage variable obtained does not have a significant effect on CSR. The results of this research show that companies that have more leverage levels do not have a certain tendency to express broader CSR. This happens because companies that have large 
leverage will try more to suppress and improve conditions company finances, compared to concentrating on corporate CSR disclosures.

\section{CONCLUSION}

The diversity on the board is crucial to remain in each company. Diversity considered capable of providing a positive change in all company activities. These changes can be seen in the performance of the company, CSR, and many other aspects. The diversity on this board includes aspects of age, experience, business, gender, nationality, ethnicity/culture, and many more. In this study, the authors used the ethnic, foreign commissioners and commissioners sexed women. The results of the presence of foreign commissioners got no influence on CSR disclosure. This occurs because of differences in the leadership styles of foreigners with natives. Commissioners' foreign nationals are considered not to have a high sense of belonging to the company. Of several companies into the sample, the proven CSR disclosure level is quite low. Many of the items were not disclosed, and any items that disclosed only in the outline only.

In the ethnic commissioners' variable obtained a significant influence on CSR disclosure. This is consistent with the general idea of the character of ethnic Chinese people who prioritize the advancement in business and has very high transparency. The existence of ethnic Chinese who dominate in the enterprise is certainly very profitable for the company in CSR disclosure. But on the other hand, it can reduce the ratio of the commissioners other ethnic groups such as Malay, Batak, Java, and others. But there are also some companies that are being sampled, in its board structure from year to year, there are ethnic Chinese. Surely there are advantages and disadvantages to each company.

Feminism commissioners in this study greatly strengthen the results of previous studies which proved the women's presence on the board can improve the CSR disclosure index. It proves also that gender equality was not kidding. Women giving roles in the company. Despite the attitude of love rush in making decisions, it is supported by the strong nature of the women who act and think in detail. The feeling is more dominating than the logic, but it is what is felt capable of making CSR it can be quite extensive and impressed so caring to the community for being very social. Therefore, the company should prioritize the diversity of the board in the presence of women.

For further research to be more detailed can use other measurements such as the BLAU index and expanded to gender to make a comparison with the composition of men on the board. This study still uses a fairly small number of samples due to the application of sustainability reports using the GRI G4 standard so little in Indonesia that it is unable to provide a broader picture of CSR disclosure from companies in Indonesia. Besides, other factors in the board structure can be further investigated such as experience, age, tenure, busyness, and many others.

\section{ACKNOWLEDGMENTS}

The authors are very grateful to the Ministry of Research-Technology and Higher Education/Ristek-Dikti who has provided funding for this research through Penelitian Dosen Pemula (PDP) grants for the year 2019 granted through Universitas Putra Indonesia "YPTK", Padang, Indonesia. 


\section{REFERENCES}

Abad, D., Lucas-Pérez, M. E., Minguez-Vera, A., \& Yagüe, J. (2017). Does gender diversity on corporate boards reduce information asymmetry in equity markets? BRQ Business Research Quarterly, 20(3), 192-205. https://doi.org/10.1016/j.brq.2017.04.001

Abdul, W. E. A., Marzuki, M. M., Jaafar, S. B., \& Masron, T. A. (2018). Board diversity and total directors' remuneration: evidence from an emerging market. Pacific Accounting Review, 30(2), 243-272. https:/ / doi.org/10.1108/PAR-02-2016-0021

Alazzani, A., Wan-Hussin, W. N., \& Jones, M. (2019). Muslim CEO, women on boards and corporate responsibility reporting: some evidence from Malaysia. Journal of Islamic Accounting and Business Research, 10(2), 274-296. https:/ / doi.org/10.1108/JIABR-01-2017-0002

Antoro, D. A., \& Hermuningsih, S. (2017). Kebijakan Dividen dan BI Rate Sebagai Pemoderasi Likuiditas, dan Leverage Terhadap Nilai Perusahaan Perbankan yang Terdaftar Di BEI. 2(1).

Ayuso, S., \& Argandoña, A. (2007). Responsible corporate governance: Towards a stakeholder board of directors? IESE Research Papers. Retrieved from https://ideas.repec.org/p/ebg/iesewp/d-0701.html

Barka, H. Ben, \& Dardour, A. (2015). Investigating the relationship between director's profile, board interlocks and corporate social responsibility. Management Decision, 53(3), 553-570. https:/ / doi.org/10.1108/MD-12-2013-0655

Bear, S., Rahman, N., \& Post, C. (2010). The Impact of Board Diversity and Gender Composition on Corporate Social Responsibility and Firm Reputation. Journal of Business Ethics, 97(2), 207-221. https:/ / doi.org/10.1007/ s10551-010-0505-2

Branco, M. C., \& Rodrigues, L. L. (2008). Factors Influencing Social Responsibility Disclosure by Portuguese Companies. Journal of Business Ethics, 83(4), 685-701. https:// doi.org/10.1007/s10551-007-9658-z

Bustami, R., Nasruddin, E., Sen, K., \& Ng, F. (2011). Ethnic Diversity in the Pluralistic Economy: Corporate Social Responsibility (CSR) in Four Critical Areas of Organizational Integration in Malaysia and Beyond. In Asian CSR and Sustainability Review (Vol. 2).

Calabrese, A., Costa, R., Ghiron, N. L., \& Menichini, T. (2018). Gender Equality Among CSR Managers and its Influence on Sustainable Development: A Comparison Among Italy, Spain and United Kingdom. European Journal of Sustainable Development, 7(4), 451-462. https:// doi.org/10.14207/ejsd.2018.v7n4p451

Cook, A., \& Glass, C. (2018). Women on corporate boards: Do they advance corporate social responsibility? Human Relations, 71(7), 897-924. https:// doi.org/10.1177/0018726717729207

Dani, A. C., Picolo, J. D., \& Klann, R. C. (2019). Gender influence, social responsibility and governance in performance. RAUSP Management Journal, 54(2), 154-177. https://doi.org/10.1108/RAUSP-07-2018-0041

Dewi, K., \& Monalisa, M. (2016). Effect of Corporate Social Responsibility Disclosure on Financial Performance with Audit Quality as a Moderating Variable. Binus Business Review, 7(2), 149. https:/ / doi.org/10.21512/bbr.v7i2.1687

DEZSŐ, C. L., \& ROSS, D. G. (2012). DOES FEMALE REPRESENTATION IN TOP MANAGEMENT IMPROVE FIRM PERFORMANCE? A PANEL DATA INVESTIGATION. Strategic Management Journal, Vol. 33, pp. 1072-1089. https://doi.org/10.2307/23261318 
Erhardt, N. L., Werbel, J. D., \& Shrader, C. B. (2003). Board of Director Diversity and Firm Financial Performance. (February). https://doi.org/10.1111/14678683.00011

Galbreath, J. (2018). Is Board Gender Diversity Linked to Financial Performance? The Mediating Mechanism of CSR. Business and Society, 57(5), 863-889. https:/ / doi.org/10.1177/0007650316647967

Giannarakis, G. (2014). The determinants influencing the extent of CSR disclosure. International Journal of Law and Management, 56(5), 393-416. https://doi.org/10.1108/IJLMA-05-2013-0021

Glass, C., Cook, A., \& Ingersoll, A. R. (2016). Do Women Leaders Promote Sustainability? Analyzing the Effect of Corporate Governance Composition on Environmental Performance. Business Strategy and the Environment, 25(7), 495511. https://doi.org/10.1002/bse.1879

Haniffa, R. M., \& Cooke, T. E. (2005). The impact of culture and governance on corporate social reporting. Journal of Accounting and Public Policy, 24(5), 391$430 . \quad$ Retrieved from https://econpapers.repec.org/article/eeejappol/v_3a24_3ay_3a2005_3ai_3a5_3a p_3a391-430.htm

Harjoto, M. A., Laksmana, I., \& Yang, Y. wen. (2019). Board nationality and educational background diversity and corporate social performance. Corporate Governance: The International Journal of Business in Society, 19(2), 217-239. https:// doi.org/10.1108/CG-04-2018-0138

Ibrahim, A. H., \& Hanefah, M. M. (2016). Board diversity and corporate social responsibility in Jordan. Journal of Financial Reporting and Accounting, 14(2), 279-298. https:// doi.org/10.1108/JFRA-06-2015-0065

Isa, M. A., \& Muhammad, S. (2014). The Impact of Board Characteristics on Corporate Social Responsibility Disclosure: Evidence from Nigerian Food Product Firms. International Journal of Management Science and Business Administration, 1(12), 34-45. https://doi.org/10.18775/ijmsba.1849-5664-5419.2014.112.1004

Kamangari, A., \& Gerayli, M. S. (2017). Board Diversity and Corporate Social Responsibility: Evidence from Iranian Firms. In Board Diversity and Corporate Social Responsibility: Evidence from Iranian Firms (Vol. 2).

Khan, A., Muttakin, M. B., \& Siddiqui, J. (2013). Corporate Governance and Corporate Social Responsibility Disclosures: Evidence from an Emerging Economy. Journal of Business Ethics, 114(2), 207-223. https:/ / doi.org/10.1007/s10551-012-1336-0

Khan, I., Khan, I., \& Saeed, B. bin. (2019). Does board diversity affect quality of corporate social responsibility disclosure? Evidence from Pakistan. Corporate Social Responsibility and Environmental Management, csr.1753. https://doi.org/10.1002/csr.1753

Louis, O., \& Osemeke, N. (2017, May 1). The role of ethnic directors in corporate social responsibility: Does culture matter? the cultural trait theory perspectives. International Journal of Disclosure and Governance, Vol. 14, pp. 152-172. https:// doi.org/10.1057/s41310-017-0018-7

Lückerath-Rovers, M. (2013). Women on boards and firm performance. Journal of Management and Governance, 17(2), 491-509. https://doi.org/10.1007/s10997011-9186-1

Lusiana, \& Rahma, A. A. (2017). Pengaruh Firm Size, Profitability, Audit Committee Size, Dan Auditor Opinion Terhadap Audit Delay Pada Perusahaan LQ-45 Yang 
Terdaftar Di Bursa Efek Indonesia Tahun 2011-2015. Majalah Ilmiah, 24(1), 191205.

MacHold, S., Ahmed, P. K., \& Farquhar, S. S. (2008). Corporate governance and ethics: A feminist perspective. Journal of Business Ethics, 81(3), 665-678. https://doi.org/10.1007/s10551-007-9539-5

Majeed, S., Aziz, T., \& Saleem, S. (2015). The Effect of Corporate Governance Elements on Corporate Social Responsibility (CSR) Disclosure: An Empirical Evidence from Listed Companies at KSE Pakistan. International Journal of Financial Studies, 3(4), 530-556. https:// doi.org/10.3390/ijfs3040530

McDonald, M. L., Keeves, G. D., \& Westphal, J. D. (2018). One step forward, one step back: White male top manager organizational identification and helping behavior toward other executives following the appointment of a female or racial minority CEO. Academy of Management Journal, 61(2), 405-439. https:// doi.org/10.5465/amj.2016.0358

Mullins, A., \& Soetanto, R. (2013). Ethnic differences in perceptions of social responsibility: informing risk communication strategies for enhancing community resilience to flooding. 119-131. https://doi.org/10.1108/09653561311325271

Nuryaman. (2013). The Effect Of Corporate Social Responsibility Actlvltes On Profitability And Stock Price. Journal of Global Management, 6(1). Retrieved from https:/ / repository.widyatama.ac.id/xmlui/handle/123456789/8806

Nussy, T. M. (2013). Corporate Governance dan Etnisitas terhadap Pengungkapan Corporate Social Responsibility. 17(1), 1-10.

Odriozola, M. D., \& Baraibar-Diez, E. (2018). Do work-life balance practices mediate in the relationship between female participation and financial performance? European Journal of Management and Business Economics, 27(3), 249-265. https://doi.org/10.1108/EJMBE-08-2017-0009

Osemeke, N., \& Osemeke, L. (2017). The Role of Ethnic Directors in Corporate Social Responsibility: Does Culture matter? The Cultural Trait Theory Perspectives . Retrieved from http://researchonline.ljmu.ac.uk/

Oxelheim, L., \& Randøy, T. (2003). The impact of foreign board membership on firm value. Journal of Banking \& Finance, 27, 2369-2392. https:/ / doi.org/10.1016/S0378-4266(02)00395-3

Rahindayati, N. M., Ramantha, I. W., \& Rasmini, N. K. (2015). PENGARUH DIVERSITAS PENGURUS PADA LUAS PENGUNGKAPAN CORPORATE SOCIAL RESPONSIBILITY PERUSAHAAN SEKTOR KEUANGAN .

Rahma, A. A., Lusiana, \& Indriani, P. (2019). Pengaruh Struktur Modal, Profitabilitas dan Size Perusahaan terhadap Ketepatan Waktu Pelaporan Keuangan pada Perusahaan Manufaktur. 210-220. https://doi.org/10.22216/jbe.v4i2.3698

Rahma, A. A., Mary, H., \& Gozali, C. (2019). Pengaruh Komposisi Dewan Komisaris terhadap Capital Structure pada Perusahaan Manufaktur. SINMAG3, 2(2).

Ramasamy, B., Ling, N. H., \& Ting, H. W. (2007). Corporate Social Performance and Ethnicity. International Journal of Cross Cultural Management, 7(1), 29-45. https://doi.org/10.1177/1470595807075169

Respati, R. D., \& Hadiprajitno, P. B. (2015). Analisis Pengaruh Profitabilitas, Leverage, Ukuran Perusahaan, Tipe Industri, Dan Pengungkapan Media Terhadap Pengungkapan Corporate Social Responsibility. Retrieved from http://ejournals1.undip.ac.id/index.php/accounting 
Rusmanto, T., Syahbandiah, V. P., \& Waworuntu, S. R. (2014). The Impact of Corporate Governance on Corporate Social Responsibility Disclosure: Evidence from Indonesia.

Said, R., Joseph, C., \& Sidek, N. Z. M. (2017). Corporate governance and corporate social responsibility (CSR) disclosure: The moderating role of cultural values. Developments in Corporate Governance and Responsibility, 12, 189-206. https:// doi.org/10.1108/S2043-052320170000012013

Sudana, I. M., \& Arlindania, P. A. (2011). Corporate Governance Dan Pengungkapan Corporate Social Responsibility Pada Perusahaan Go-Public Di Bursa Efek Indonesia. Jurnal Manajemen Teori Dan Terapan | Journal of Theory and Applied Management, 4(1). https:/ / doi.org/10.20473/JMTT.V4I1.2411

Suhardjanto, D., \& Permatasari, N. D. (2010). Pengaruh Corporate Governance, Etnis, dan Latar Belakang Pendidikan Terhadap Environmental Disclosure. Kinerja, 14(2), 151-164. Retrieved from https://media.neliti.com/media/publications/164653-ID-pengaruh-corporategovernance-etnis-dan.pdf

Tan, M. G. (2005). Ethnic Chinese in Indonesia. In Encyclopedia of Diasporas (pp. 795808). https:/ / doi.org/10.1007/978-0-387-29904-4_82

Wan Mohammad, W. M., Wasiuzzaman, S., \& Nik Salleh, N. M. Z. (2016). Board and audit committee effectiveness, ethnic diversification and earnings management: a study of the Malaysian manufacturing sector. Corporate Governance (Bingley), 16(4), 726-746. https:// doi.org/10.1108/CG-06-2015-0085

Williams, R. J. (2003). Women on Corporate Boards of Directors and their Influence on Corporate Philanthropy. Journal of Business Ethics, 42(1), 1-10. https://doi.org/10.1023/A:1021626024014

Yunos, R. M., Ismail, Z., \& Smith, M. (2012). Ethnicity and accounting conservatism: Malaysian evidence. Asian Review of Accounting, Vol. 20, pp. 34-57. https://doi.org/10.1108/13217341211224718

Zaid, M. A. A., Wang, M., \& Abuhijleh, S. T. F. (2019). The effect of corporate governance practices on corporate social responsibility disclosure. Journal of Global Responsibility, 10(2), 134-160. https:/ / doi.org/10.1108/JGR-10-2018-0053

Zhang, J. Q., Zhu, H., \& Ding, H. (2013). Board Composition and Corporate Social Responsibility: An Empirical Investigation in the Post Sarbanes-Oxley Era. Journal of Business Ethics, Vol. 114, pp. 381-392. https://doi.org/10.2307/23433787 